\title{
Differential effects of focused and unfocused recasts on EFL learners' oral accuracy
}

\section{Efectos diferenciados en la precisión oral de los aprendices del inglés como lengua extranjera}

\author{
Ali Akbar Ansarin' \\ Mohammad Hassan Chehrazad ${ }^{2}$
}

Citation / Para citar este artículo: Ansarin, A. \& Chehrazad, M. (2015). Differential effects of focused and unfocused recasts on the EFL learners' oral accuracy. Colomb. Appl. Linguist. J., 17(1), pp. 86-97.

Received: 11-Aug-2014 / Accepted: 11-Feb-2015

DOI: http://dx.doi.org/10.14483/udistrital.jour.calj.2015.1.a06

\begin{abstract}
One of the limitations of meaning-focused instruction in the EFL context is that a communicative approach is not sufficient enough to ensure higher levels of oral accuracy. The purpose of the current study was to investigate the effects of two different focus-on-form techniques, unfocused and focused recasts, on EFL learners' oral accuracy. Three pre-intermediate intact classes were randomly selected as the focused recast, unfocused recast, and control groups. In the focused recast group, the focus of correction was on simple past tense errors. In the unfocused recast group, the recast was provided for all errors. In the control group, there was no corrective feedback. Learners' oral accuracy as the number of Error-free T-units per T-units was measured. One-way ANOVAs indicated that the differences among groups were only significant in sessions five and six. Tukey's HSD (honest significant difference) indicated that the focused recast group outperformed both the unfocused and the control groups in these sessions and there were no significant differences between the other two groups. These findings suggest that focus on form can be an effective tool for the development of the oral accuracy in EFL situations. In addition, recasting learners' oral errors could enhance oral accuracy.
\end{abstract}

Keywords: Accuracy, focused (intensive) recast, unfocused (extensive) recast

\section{Resumen}

Una de las limitaciones de la enseñanza centrada en el significado en el contexto EFL es que un enfoque comunicativo no es suficiente para garantizar un mayor nivel de precisión oral. El objetivo del presente estudio fue investigar los efectos de dos técnicas diferentes de enfoque en forma, reformulaciones desenfocadas y enfocadas, sobre la precisión oral de estudiantes de inglés como lengua extranjera (EFL). Tres clases pre-intermedias intactas fueron seleccionadas al azar como la reformulación enfocada, reformulación fuera de foco, y los grupos de control. En el grupo de reformulación enfocada, el foco de la corrección era en los errores en tiempo pasado simples. En el grupo de reformulación fuera de foco, se proporcionó la reformulación de todos los errores. En el grupo de control, no hubo retroalimentación correctiva. Se midió la precisión oral de los alumnos como el número de T-unidades por T-unidades sin errores. One-way ANOVA indicó que las diferencias entre los grupos sólo fueron significativas en sesiones de cinco y seis. El examen HSD (honest significant difference) de Turquía indicó que el grupo de reformulación enfocado

1 University of Tabriz, Tabriz, Iran. ansarin@tabrizu.ac.ir

2 University of Tabriz, Tabriz, Iran. chehrazad88@ms.tabrizu.ac.ir 
superó tanto a los grupos fuera de foco y el grupo de control en estas sesiones y no hubo diferencias significativas entre los otros dos grupos. Estos hallazgos sugieren que la atención a la forma puede ser una herramienta eficaz para el desarrollo de la precisión oral en contextos de inglés como lengua extranjera. Además, reformular los errores orales de los alumnos podrían mejorar la precisión oral.

Palabras clave: precisión, reformulación enfocada (intensiva), reformulación fuera de foco (extensiva)

\section{Introduction}

There is an ever-growing consensus among L2 researchers that, in order to be effective, task-based syllabuses, and analytical approaches in general, need to be augmented, at least at times by some type of grammar instruction (Ellis, 2003; Long, 2000). This was based on studies showing that learners, if left completely to their own devices, are unlikely to attain native-like grammatical competence, despite even extensive contact with the target language (e.g., Long \& Robinson, 1998). For example, evaluations of French immersion programs in Canada have found that learners typically become fluent and comprehend L2 at native levels as a result of content-based instruction, and yet, "their productive skills remain far from native like, particularly with respect to grammatical competence" (Swain, 1991, p.98). Recognition of these types of problems led to the introduction of focus on form by Long (1991). It attempts to capture the strengths of an analytic approach while dealing with its limitations. Long and Robinson (1998) define focus on form instruction as:

During a meaning-focused classroom lesson, focus on form often consists of an occasional shift of attention to linguistic code features by the teacher and/or one or more of the students, triggered by perceived problem with comprehension or production. (p. 23)

Focus on form can be classified from different perspectives. Ellis (2001) categorized it into planned and incidental focus on form. In planned focus on form, pre-selected linguistic items are targeted during a meaning-focused activity. Planned focus on form can be realized either through input flood
(Trahey \& White, 1993) and input enhancement (Sharwood Smith, 1993), or output in the form of corrective feedback on errors in the use of pretargeted forms (Ellis, 2001). Incidental focus on form (Ellis, 2001) occurs spontaneously, without prior intention, during meaning-focused activities and targets a variety of linguistic items. While planned focus on form is intensive, focusing frequently on the same linguistic structure, incidental focus on form has a more extensive focus, with many linguistic structures being targeted but on only one or two occasions (Ellis, Basturkmen, \& Loewen, 2001a).

It can be also classified in terms of explicitness or implicitness. Doughty and Williams (1998) assert that focus on form interpretations vary from a very narrow and implicit view introduced by Long (1991) to a general, liberal, and more explicit view suggested in the findings of Dekeyser (1998) and Swain (1998). Since explicit feedback depends on metalinguistic information to sustain error correction, students must comprehend the language used in the metalinguistic explanation. Thus, students who do not have the specialized vocabulary and grammar awareness may not be able to make use of this feedback (Carroll \& Swain, 1993). On the other hand, implicit feedback indirectly and incidentally makes learners aware of their non-target-like use of certain linguistic features.

Another distinction that has been made concerns reactive and preemptive focus on form (Ellis, Basturkmen, E Loewen, 2001a, 2001b; Long E Robinson, 1998). While Long claims that focus on form is purely reactive, Ellis (2001) claims that it comes in two forms: preemptive focus on form and reactive focus on form. Preemptive focus on form 
occurs when either the teacher or a learner initiates attention to form, generally by raising a question, even though no actual problem in production has arisen. Reactive focus on form, in contrast, has been known as error correction, corrective feedback, or negative evidence/feedback (Long, 1996), and occurs when, in the context of meaning-focused activities, learners' attention is drawn to errors in their production.

There are different techniques and options for operationalizing the reactive focus on form. One of these options is recast. It is an utterance that "rephrases the learner's utterance by changing one or more components (subject, verb, object) while still referring to its central meaning" (Long, 1996, p. 436).

Recast and its nature can be considered from multiple perspectives. The first perspective can be based on its implicit or explicitness. The prevailing view in the recast literature is that recasts constitute an implicit form of negative feedback. According to Ellis (2008), "recasts should not be viewed as necessarily implicit but rather depending on the linguistic signals that encode them and the discoursal context, as more or less implicit/explicit" (p. 230). Corrective recasts are clearly explicit, as is evident in this example from Doughty and Varela (1998):

L: I think that the worm will go under the soil.

T: I think that the worm will go under the soil?

L: (no response)

T: I thought that the worm would go under the soil.

L: I thought that the worm would go under the soil.

Another perspective can be related to the nature of the evidence it provides. According to Ellis and Sheen (2006), recasts can serve as both positive and negative evidence if learners perceive the teacher's corrective intention but only as positive evidence if learners are not consciously aware of their illocutionary force (see also Leeman, 2003). Although there is evidence that recasts affording just positive evidence can facilitate acquisition, it remains possible (but not yet demonstrated) that recasts that supply both positive and negative evidence are even more effective.

Recasts can also be categorized into intensive and extensive recasts. Focused (intensive) recasts are directed at a single structure (as in Doughty \& Varela's, 1998), and encourage the treatment of recasts as an explicit feedback. On the other hand, unfocused (extensive) recasts are directed at different structures, and encourage the treatment of recasts as an implicit feedback.

There have been several studies comparing the effects of focus-on-form techniques, particularly recasts, on the different aspects of second language development. For example, Doughty and Varela (1998) conducted an empirical study examining the effects of recasting on L2 learning in the context of a content-based ESL science class in the United States. In their study, the instructor provided learners with corrective recasts whenever past or conditional errors occurred in speaking and writing. Results indicated that learners who were given recasts showed greater improvements in accuracy and a higher total number of attempts at past-time reference than the control group.

Long, Inagaki, and Ortega (1998) reported the results of two experiments conducted to assess the relative utility of models and recasts in L2 Japanese and Spanish. Each study provided some evidence of adult L2 learners to learn from implicit negative feedback, and, in their Spanish L2 study, they found evidence that recasts were more effective than models in achieving at least short-term improvements on a previously unknown L2 structures. Mackey and Philip (1998) also investigated the effects of recasts on ESL learners' interlanguage development of question forms by comparing groups of ESL learners who received interactionally modified input with learners who received the same input containing recasts. Their results also suggest that recasts may be beneficial even when they are not incorporated into learners' immediate responses. Lyster and Ranta (1997) found that recasts were 
less effective in eliciting student-generated repair than other types of feedback: clarification requests, repetition, metalinguistic feedback, and elicitation. Their results, along with the results of other recast studies focusing on particular forms (e.g., Doughty \& Varela, 1998; Mackey \& Philip, 1998) suggest that recasts might have weaker effects on L2 learning when they do not focus on specific forms. In general, the recast studies demonstrated that implicit feedback of this kind can have a beneficial effect on acquisition, especially when the recasts are more explicit in nature (as in Doughty $\mathcal{E}$ Varela, 1998).

Ellis, Loewen, and Erlam (2006) investigated the differential effects of recasts and metalinguistic feedback on the acquisition of the regular past tense in English and found that metalinguistic feedback was overall more effective than recasts.

Nassaji (2009) investigated the effects of two categories of interactional feedback-recasts and elicitations - on learning linguistic forms that arose incidentally in dyadic interaction and found a higher degree of immediate post interaction correction for recasts than for elicitations. The results also showed that in both cases the more explicit forms of each feedback type led to higher rates of immediate and delayed post interaction correction than the implicit forms. However, the effects of explicitness were more pronounced for recasts than for elicitations.

Lyster and Saito (2010) conducted a metaanalysis of 15 classroom studies of oral corrective feedback (CF). They found that classroom learners were able to benefit from the positive evidence available in recasts as well as from the opportunities recasts provide to infer negative evidence.

Yang and Lyster (2010) compared the differential effects of recasts, prompts, and non-corrective feedback on the use of regular and irregular past tense forms by undergraduate English majors. The effects of prompts were larger than those of recasts for increasing accuracy in the use of regular pasttense forms, while prompts and recasts had similar effects on improving accuracy in the use of irregular past-tense forms.

Rassaei (2013) studied whether learners' perceptions of two types of oral corrective feedback were influenced by their foreign language anxiety in the classroom. The analysis of learners' perceptions along with their anxiety level indicated that the low anxiety level learners were more successfully able to notice the gap between their erroneous utterances and target-like forms, and consequently, recognize as corrective both the recasts and metalinguistic feedback.

Rassaei (2014) also examined whether learners with field independent and field dependent cognitive styles benefit differently from recasts and found that only field independent learners benefited from recasts.

The main limitation of the research to date is that there is little information available regarding the investigation of the effects of focused and unfocused types of recasts, on EFL learners' oral accuracy. Considering this limitation and due to the fact that communicative language teaching in Iranian English institutes leads to higher levels of fluency at the expense of lower levels of accuracy, the purpose of this study was to investigate the effects of focused and unfocused recasts on Iranian EFL learners' oral accuracy. To this end, the following research questions were formulated.

1. Do learners who have received focused (intensive) recasts on their simple past tense errors show greater improvement on their oral accuracy than learners who have received no feedback?

2. Do learners who have received unfocused (extensive) recasts on their all grammatical errors show greater improvement on their oral accuracy than learners who have received no feedback?

3. Do learners who have received focused recasts on their oral simple tense errors show greater improvement on their oral accuracy than those who have received unfocused recasts on their all oral grammatical errors? 


\section{Methods}

\section{Participants}

The present study was conducted at an English school in Tabriz, Iran. Three intact classes including 54 pre-intermediate students were selected. All were from Tabriz and were speakers of Azeri. The participants were males between the ages of 15 and 23 . The course they were taking was based on taskbased language teaching. Their weekly attendance at school was three sessions of 4.5 hours. They had no or little opportunity for informal interaction in English outside the classroom. The general English test, KET (Key English Test), was used to establish the participants' homogeneity. The accepted mark for participation of the individual students of each group was 40-55.

\section{Target structure}

The focus of this study was on both the regular and irregular simple past tense which were chosen for two reasons. First, learners at the lower intermediate level are likely to be familiar with this structure. The purpose was not to examine whether corrective feedback assists learning of completely new structure, but whether it enables learners to gain greater control over a structure they have already partially mastered. The second reason was that past tense is known to be problematic for learners and to cause errors (Doughty $\&$ Varela, 1998). Thus, it was hypothesized that although learners at this level would have a partial explicit knowledge of this structure, they would make errors in its use, especially in oral production.

\section{Design of the study}

In this quasi-experimental research, the independent variable of the study was recast which is a type of error correction and which was provided at two levels of focused and unfocused recasts. The dependent variable was oral accuracy. The intact classes were randomly chosen as the control, focused recast, and unfocused recast groups. The participating groups are shown in Table 1 .

The control group and the two recast groups differed according to the opportunity of the participants to receive feedback in the story retelling task. That is, unlike the participants of the two recast groups who received feedback on their grammatical errors, the control group's participants received no feedback.

Table 1. Participating Groups and their Specific Characteristics

\begin{tabular}{cccc}
\hline Group & $\begin{array}{c}\text { Number of } \\
\text { participants }\end{array}$ & Existence of Focus on Form & Type of Focus on Form \\
\hline $\begin{array}{c}\text { Control } \\
\text { Intensive recast } \\
\text { (experimental 1) }\end{array}$ & 19 & No & Yes \\
$\begin{array}{c}\text { Extensive recast } \\
\text { (experimental 2) }\end{array}$ & 17 & Yes & $\begin{array}{c}\text { No } \\
\text { errors }\end{array}$ \\
\hline
\end{tabular}

The focused and unfocused recast groups differed in terms of the type of recasts they received. That is, while the focused recast group received recasts which were intensively based on their simple past tense errors, the unfocused recast group received recasts which were extensively based on all of their grammatical errors during the treatment sessions.

\section{Procedures}

Although all participants were at the low intermediate level based on the placement test of the school and their scores on the achievement tests of the previous terms, two sessions before starting the treatment sessions, the general English test, KET (Key English Test) was used and those who scored between 40-55 were selected as the participants of 
the study. The instructional treatment was provided during six training sessions. The first half of each session of the instruction was based on the school's regular program which lasted about 45 minutes. The second half of each session was for both the story retelling task, common to the control and experimental groups, and the treatment part that was different for the control and experimental groups.

In each session of the study, six sessions in total, which were tape recorded for the later analysis, all participants were assigned one story from Steps to Understanding (Hill, 1988) in a way that the assigned stories within groups were different, and the stories between groups were exactly the same. After the assignment of the stories, they were given four minutes and were asked to read and summarize what they had read. The reason for this kind of time limit was to prevent them from memorizing the story. When they finished reading and summarizing their own specific stories, they were asked to retell it to the class without any time limitations. During the retelling of the story which was audio recorded for later analysis, the three groups differed with respect to the presence or absence of feedback and the kind of feedback they received. In other words, whereas the control group's members received no feedback on their errors, the experimental group's members did.

In addition to the difference between the experimental groups and the control group, the two experimental groups differed in terms of the type and the focus of the recast they received. While the first experimental group's members received intensive recast on their simple past tense errors, the second experimental group's members received extensive recast on all grammatical errors they made. This process continued in every session of the study in the same manner. When the treatment sessions finished, the oral data was transcribed and coded for analysis. To this end, the recorded data for all groups and their members in every session of the treatment were transcribed and analyzed. Since the focus of the study was on the effects of feedback on oral accuracy, the data were transcribed and coded with respect to the accurate use of simple past tense.

The accuracy which concerns "the extent to which the language produced conforms to target language norms" (Skehan, 1996, p. 22), following the previous studies of Mehnert (1998), YaghubiNotash (2007), and Farrokhi and Chehrazad (2012), was operationalized as the number of Error-free T-units per T-units i.e., the percentage of T-units that do not contain any simple past tense errors. T-unit is defined as "one main clause plus whatever subordinate clauses, phrases, and words happen to be attached or embedded within it" (Mehnert, 1998, p. 91). The inter-rater reliability for coding was obtained by having another instructor identify and code the data. The reliability was 0.89 . The groups' scores during the six sessions of the study were submitted to another one way ANOVA for further analysis. In order to find out which of the groups and in which sessions of the study differed significantly from one another, a Tukey's HSD test was used.

\section{Results}

To initially establish the homogeneity of the variances and consequently address one of the basic assumptions of the parametric tests, Levene's test was used. The results of this test for all six sessions are presented in Table 2.

Table 2. Levene's Test of Homogeneity of Variances

\begin{tabular}{ccccc}
\hline & Levene's Statistics & df1 & df2 & Sig. \\
\hline Session 1 & 1.022 & 2 & 51 & .367 \\
Session 2 & 1.022 & 2 & 51 & .367 \\
Session 3 & .507 & 2 & 51 & .605 \\
Session 4 & .600 & 2 & 51 & .553 \\
Session 5 & .889 & 2 & 51 & .417 \\
Session 6 & 2.511 & 2 & 51 & .091 \\
\hline
\end{tabular}


Based on the results of this test for all sessions, the significance level is above .05 which means that all groups in all sessions have equal variances. That is, all groups' variances in all sessions of the study are homogenous; consequently, we chose a oneway ANOVA test. The results of the one-way ANOVA are illustrated in Table 3.

As it is depicted in Table 3, in the first four sessions, the group differences were not statistically significant $(p>.05)$. On the contrary, considering the results of session 5 in which $F(2$,
$51)=3.887, p<.05$ and session 6 in which $F$ $(2,51)=5.799, p<.05$, the difference among groups was statistically significant. The effect size, Cohen's $d$, were $d=.013$ and $d=.018$ in sessions 5 and 6 respectively indicating that between groups difference account for $13 \%$ and $18 \%$ of the variance in the scores.

Having found that the group differences were only significant in sessions five and six, these sessions' data were submitted to a Tukey's HSD test. The results of this test are shown in Table 4.

Table 3. Summary of the Results of the One-Way ANOVA

\begin{tabular}{|c|c|c|c|c|c|c|c|}
\hline & & Sum of Squares & df & Mean Square & $\mathbf{F}$ & Sig. & Cohen's d \\
\hline & Between Groups & 275.140 & 2 & 137.570 & .378 & .687 & \\
\hline \multirow[t]{3}{*}{ Session 1} & Within Groups & 18567.429 & 51 & 364.067 & & & \\
\hline & Total & 18842.569 & 53 & & & & \\
\hline & Between Groups & 46.371 & 2 & 23.185 & .067 & .935 & \\
\hline \multirow[t]{3}{*}{ Session 2} & Within Groups & 17629.162 & 51 & 345.670 & & & \\
\hline & Total & 17675.533 & 53 & & & & \\
\hline & Between Groups & 1886.159 & 2 & 943.080 & 2.828 & .068 & \\
\hline \multirow[t]{3}{*}{ Session 3} & Within Groups & 17009.071 & 51 & 333.511 & & & \\
\hline & Total & 18895.230 & 53 & & & & \\
\hline & Between Groups & 901.259 & 2 & 450.630 & 1.713 & .190 & \\
\hline \multirow[t]{3}{*}{ Session 4} & Within Groups & 13413.427 & 51 & 263.008 & & & \\
\hline & Total & 14314.686 & 53 & & & & \\
\hline & Between Groups & 2620.457 & 2 & 1310.229 & 3.887 & $.027 *$ & .013 \\
\hline \multirow[t]{2}{*}{ Session 5} & Within Groups & 17188.987 & 51 & 337.039 & & & \\
\hline & Total & 19809.444 & 53 & & & & \\
\hline \multirow[t]{3}{*}{ Session 6} & Between Groups & 2352.488 & 2 & 1176.244 & 5.799 & $.005^{*}$ & .018 \\
\hline & Within Groups & 10345.369 & 51 & 202.850 & & & \\
\hline & Total & 12697.857 & 53 & & & & \\
\hline
\end{tabular}

Table 4. Results of Tukey HDS Test of Sessions Five and Six of the Study.

\begin{tabular}{|c|c|c|c|c|c|c|}
\hline \multicolumn{3}{|l|}{ Dependent Variable } & \multirow{2}{*}{$\begin{array}{c}\text { Mean Difference } \\
(\mathbf{I}-\mathbf{J})\end{array}$} & \multirow{2}{*}{ Std. Error } & \multirow{2}{*}{ Sig. } & \multirow{2}{*}{ Cohen's d } \\
\hline & (I) Feedback & (J) Feedback & & & & \\
\hline \multirow{6}{*}{$\begin{array}{c}\text { Session } 5 \\
\text { Tukey HSD }\end{array}$} & \multirow[b]{2}{*}{ extensive } & control & -5.40219 & 6.03848 & .646 & \\
\hline & & intensive & $-16.83406 *$ & 6.12901 & $.022 *$ & \\
\hline & \multirow{2}{*}{ control } & extensive & 5.40219 & 6.03848 & .646 & \\
\hline & & intensive & -11.43186 & 6.20888 & .167 & \\
\hline & \multirow{2}{*}{ intensive } & extensive & $16.83406 *$ & 6.12901 & .022 & 1.28 \\
\hline & & control & 11.43186 & 6.20888 & .167 & \\
\hline \multirow{6}{*}{$\begin{array}{l}\text { Session } 6 \\
\text { Tukey HSD }\end{array}$} & \multirow{2}{*}{ extensive } & control & .83143 & 4.68463 & .983 & \\
\hline & & intensive & $-13.78755^{*}$ & 4.75486 & $.015 *$ & \\
\hline & \multirow{2}{*}{ control } & extensive & -.83143 & 4.68463 & .983 & \\
\hline & & intensive & $-14.61899 *$ & 4.81683 & .010 & \\
\hline & \multirow{2}{*}{ intensive } & extensive & $13.78755^{*}$ & 4.75486 & $.015^{*}$ & 0.86 \\
\hline & & control & $14.61899 *$ & 4.81683 & $.010 *$ & 1.29 \\
\hline
\end{tabular}


Considering session 5, comparisons using Tukey's contrasts found a statistical difference between the unfocused and focused groups (mean difference $=16.83,95 \% \mathrm{Cl}=2.03,31.62, \mathrm{p}=.022$ but not between the unfocused and control groups (mean difference $=5.40,95 \% \mathrm{Cl}=-9.17,19.97, \mathrm{p}=.646$ ) or between the focused and control groups (mean difference $=11.43,95 \% \mathrm{CI}=-3.55,26.42, \mathrm{p}=.167$ ).

Considering session 6, comparisons using Tukey's test found a statistical difference between the unfocused and focused recast groups (mean difference $=13.78,95 \% \mathrm{CI}=2.30,25.26, \mathrm{p}=.015$ and between the focused and control groups (mean difference $=14.61,95 \% \mathrm{CI}=2.99,26.24, \mathrm{p}=.01$ ) but not between the unfocused and control groups (mean difference $=.83143,95 \% \mathrm{CI}=-10.47$, 12.14, $\mathrm{p}=.983$ ).

Effect sizes for all of the significant comparisons showed quite strong effects. For focused-unfocused groups in session 5, it was 1.28. For focusedunfocused groups in session 6 , it was 0.86 . For focused-control groups in session 6, it was 1.29.

To find out which group(s) outperformed the others, there was a need to test the descriptive statistics of these groups in both sessions 5 and 6 . The descriptive statistics of all groups in session 5 are depicted in Table 5. The differences among the means of the percentages of error free clauses of all groups in session 5 are also shown in Figure 1.

Table 5. Descriptive Statistics of all Groups in Session 5Figure 1 here.

\begin{tabular}{cccc}
\hline Group & N & Mean & Std. Deviation \\
\hline Extensive recast & 19 & 63.8795 & 19.44731 \\
Control & 18 & 69.2817 & 16.32941 \\
Intensive recast & 17 & 80.7135 & 19.11868 \\
\hline
\end{tabular}

Figure 1. A Comparison of the Means in Session 5

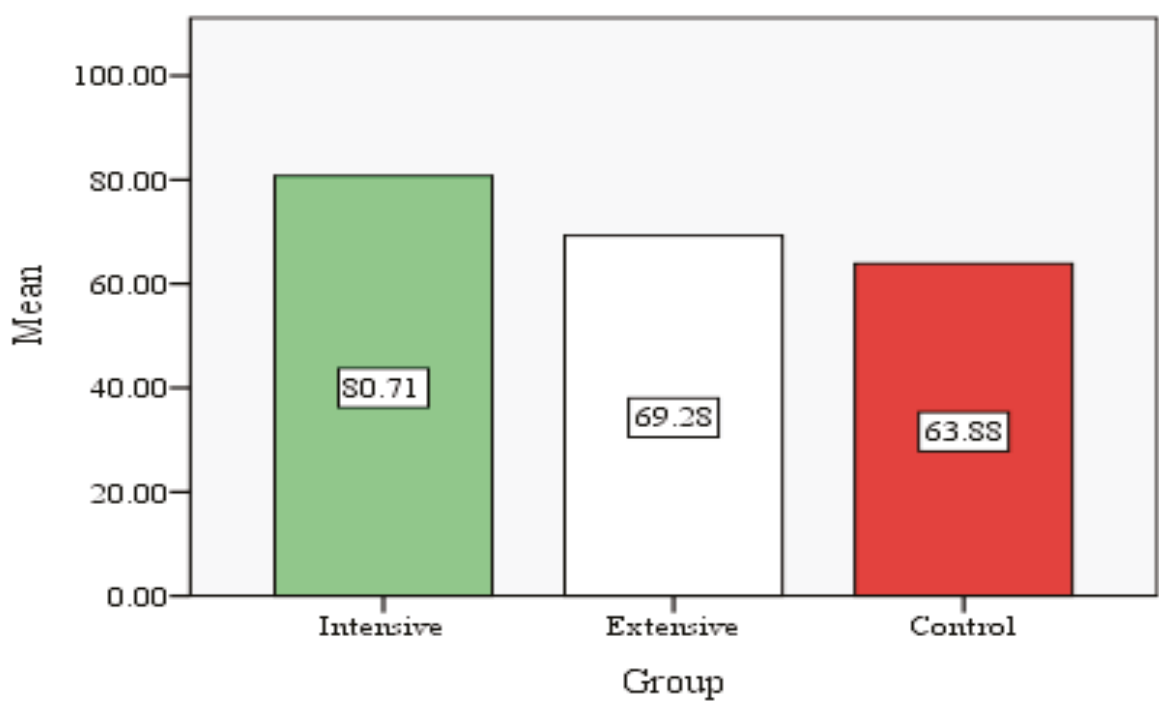


Based on the results of the Tukey's test, significant differences were found between focused and unfocused groups, and due to the fact that the focused recast group's mean was more than that of the unfocused recast group, this group significantly outperformed the unfocused recast group in session 5 .

The descriptive statistics of all groups in session 6 are depicted in Table 6 . The differences among the means of the percentages of error free clauses of all groups in session 6 are shown in Figure 2.

Based on the results of the Tukey's test, significant differences were found between focused and unfocused groups, and due to the fact that focused recast group's mean was more than that of the unfocused recast and control groups, this group significantly outperformed both groups in session 6 .

\section{Discussion and conclusion}

The first research question of the current study was that if learners who have received focused recasts on their simple past tense errors in their story retellings show greater improvement on their oral accuracy than those who have received no feedback. The answer is yes. The findings indicated that the focused recast group statistically outperformed the control group in the session 6 .

Table 6. Descriptive Statistics of all Groups in Session 6

\begin{tabular}{cccc}
\hline Group & N & Mean & Std. Deviation \\
\hline Extensive & 19 & 66.4042 & 18.47395 \\
Control & 18 & 65.5728 & 10.06531 \\
Extensive & 17 & 80.1918 & 12.44973 \\
\hline
\end{tabular}

Figure 2. A Comparison of the Mean s in Session 6

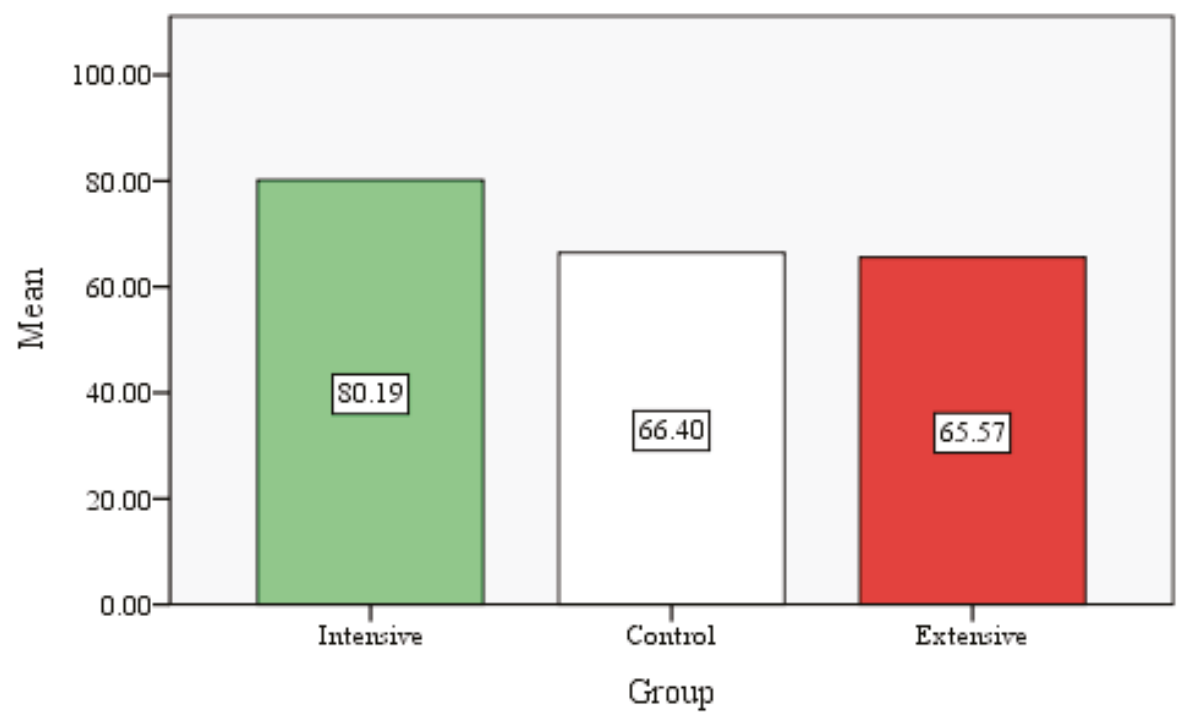


The second research question was that if learners who have received unfocused recasts on all grammatical errors in their story retellings show greater improvement on their oral accuracy than those who have received no feedback. The answer is no. The findings indicated that unlike the differences between the focused recast group and the control group, there was no significant difference between the unfocused recast group and the control group regarding the development of oral accuracy. Indeed, the provision of the unfocused recast and lack of feedback were equally effective in the development of oral accuracy. Considering these findings, it could be suggested that the unfocused recasts are not different from lack of feedback.

The third research question was if learners who have received focused recasts on the simple past tense errors in their story retellings show greater improvement on their oral accuracy than those who have received unfocused recasts. The answer is yes. Reaction to the learners' errors through the provision of recast which is intensively focused on the single grammatical error is more effective than recast which is extensively based on all grammatical errors.

Considering research question one, the findings from the present study provide support to the claim that embedding CF within communicative activities is more effective than participation in such activities without CF. The results are consistent with previous claims for the efficacy of focus on from (Doughty \& Williams, 1998; Long, 1996; Long \& Robinson, 1998; Skehan, 1996; Spada \& Lightbown, 1993).

The results of the current study provide partial support for Lightbown and Spada's (1990) claim that "accuracy, fluency, and overall communicative skills are probably best developed through instruction that is primarily meaning focused but in which guidance is provided through timely form focused activities and correction in context" (p. 443).

They also provide support for previous feedback studies (e.g., Doughty \& Varela, 1998) which revealed that negative feedback is beneficial to L2 learning when it specifically targets particular forms.
The results are in line with Yang and Lyster (2010) who compared the differential effects of recasts, prompts, and no $\mathrm{CF}$ on the use of regular and irregular past tense forms by undergraduate English majors. The effects of prompts were larger than those of recasts for increasing accuracy in the use of regular past-tense forms, while prompts and recasts had similar effects on improving accuracy in the use of irregular past-tense forms.

The results also support Lyster and Saito (2010) who conducted a meta-analysis of 15 classroom studies of oral CF. They found that classroom learners are able to benefit from the positive evidence available in recasts as well as from the opportunities recasts provide to infer negative evidence.

They are also in line with Saito and Lyster (2012) who investigated the pedagogical value of recasts on the acquisition of / $r$ / by adult Japanese learners of English. According to the results of the listener judgment and acoustic analyses, only those who received recasts during the tasks demonstrated gains, not only at a controlled-speech level, measured via word and sentence reading, but also at a spontaneous-speech level, measured via a timed picture description task.

The results are, however, in sharp contrast with the proponents of non-interface hypothesis such as Krashen (1982) who referred to "error correction as a serious mistake and argued that it should be limited to rules that can be learnt" (p. 74).

Both the absence of a statistically significant difference between the unfocused recast group and the control group, and the presence of a statistically significant difference between the unfocused and focused recast groups suggest that providing learners with recasts which are extensively based on all types of grammatical errors cannot be an effective strategy for the improvement of learners' oral accuracy. Furthermore, it suggests that for a recast strategy to be effective it needs to be focused on a single structure. The explanation for the absence of a significant difference between the unfocused recast and control group can be related to focus of the different recast types and noticing. That is, when 
the scope of a recast is broad and is extensively focused on different grammatical errors, learners do not notice its focus and, consequently, it remains unnoticed and the learners cannot recognize its corrective function and the gaps between their own utterances and the corrected forms. In this respect, the findings are consistent with Carroll (2001) who claims that corrective feedback cannot facilitate learning unless learners recognize its corrective function. Another explanation, especially for the presence of the difference between the effects of unfocused and focused recasts, might be related to the different nature of these two types of recasts. The focused recasts were narrowly directed at a single structure, the simple past tense, and their illocutionary force as corrections was quite transparent. They should, therefore, be seen as an explicit form of feedback according to Ellis (2008). On the other hand, the unfocused recasts were directed at different structures and their illocutionary force as corrections was not as clear as that of the intensive recasts. Regarding the limitations of the study, the length of treatments was very short and took only six sessions. In addition, the present research included only two types of corrections and the focus was on a single structure. Another limitation was related to the focus of the study which was on the effects of feedback on oral accuracy in a way that the study of its effects on fluency and complexity were completely ignored. Further research needs to be done to address these limitations. An additional limitation may be related to the disregard of the relationship between the number of provided recasts in each of the participating groups and the learners' accuracy developments.

With respect to the pedagogical implications, the study provides strong support for the assumption that a timely combination of formal instruction and communication-oriented instruction is highly beneficial to L2 learners especially in an EFL situation in which the instruction is based on communicative language teaching. The results of this study also suggest that the integration of planned focus on form into meaning-based activities can positively affect L2 learning when it has a particular linguistic focus.

\section{References}

Carroll, S. (2001). Input and evidence: The raw material of second language acquisition. Amsterdam: Benjamins.

Carroll, S., E Swain, M. (1993). Explicit and implicit negative feedback: An empirical study of the learning of linguistic generalizations. Studies in Second Language Acquisition, 15(3), 357-366.

Dekeyser, R. (1998). Beyond focus on form: Cognitive perspectives on learning and practicing second language grammar. In C. Doughty $\mathcal{E}$ J. Williams (Eds.), Focus on form in classroom second language acquisition (pp.42-63). Cambridge; Cambridge University Press.

Doughty, C, J., \& Varela, E. (1998). Communicative focus on form. In C. J. Doughty \& J. Williams (Eds.), Focus on form in classroom second language acquisition (pp. 114-138). New York: Cambridge University Press.

Doughty, C. J., \& Williams, J. (1998). Pedagogical choices in focus on from. In C. J. Doughty $\mathcal{E}$ J. Williams (Eds.), Focus on form in classroom second language acquisition (pp. 197-261). New York: Cambridge University Press.

Ellis, R. (2001). Investigating form-focused instruction. Language Learning, 51(1), 1-46.

Ellis, R. (2003). Task based language learning and teaching. Oxford, UK: Oxford University Press.

Ellis, R. (2008). The study of second language acquisition. Oxford: Oxford University Press.

Ellis, R., Basturkmen, H., \& Loewen, S. (2001a). Learner uptake in communicative ESL lessons. Language Learning, 51(2), 281-318.

Ellis, R., Basturkmen, H., \& Loewen, S. (2001b). Preemptive focus on form in the ESL classroom. TESOL Quarterly, 35(3), 407-432.

Ellis, R., \& Sheen, Y. (2006). Reexamining the role of recasts in second language acquisition. Studies in Second Language Acquisition, 28(4), 575-600.

Ellis, R., Loewen, S., Erlam, R. (2006). Implicit and explicit corrective feedback and the acquisition of L2 grammar. Studies in Second Language Acquisition, 28, 339-368.

Farrokhi, F., \& Chehrazad, M. H. (2012). The effects of planned focus on form on Iranian EFL learners' oral accuracy. World Journal of Education, 2(1), 70-81. http://dx.doi.org/10.5430/wje.v2n1p70

Hill, L. A. (1988). Steps to understanding. Oxford: Oxford University Press. 
Krashen, S. (1982). Principals and practice in second language acquisition. Oxford: Pergamon.

Leeman, J. (2003). Recasts and second language development: Beyond negative evidence. Studies in Second Language Acquisition, 25(1), 37-63.

Lightbown, P. M., E Spada, N. (1990). Focus on form and corrective feedback in communicative language teaching: Effects on second language learning. Studies in Second Language Acquisition, 12(4), 429-448.

Long, M. H. (1991). Focus on form: A design feature in language teaching methodology. In K. De Bot, R. Ginsberg, \& C. K. Krasch (Eds.), Foreign language research in cross-cultural perspective (pp. 39- 52). Amsterdam: Benjamins.

Long, M. H. (1996). The role of the linguistic environment in second language acquisition. In W. C. Ritchie $\& \mathrm{~T}$. K. Bhatia (Eds.), Handbook of language acquisition (pp. 413-468). San Diego: Academic Press.

Long, M. H. (2000). Task based language teaching. Oxford: Blackwell.

Long, M. H., Ingaki, S., E Ortega, L. (1998). The role of implicit negative feedback in SLA: Models and recasts in Japanese and Spanish. The Modern Language Journal. 82(3), 357-371.

Long, M. H., \& Robinson, P. (1998). Focus on form: Theory, research and practice. In C. J. Dougthy $\mathcal{E}$ J. Williams (Eds.). Focus on form in classroom second language acquisition (pp. 15-41). New York: Cambridge University Press.

Lyster, R., \& Ranta, L. (1997). Corrective feedback and the learner uptake: Negotiation of form in communicative classrooms. Studies in Second Language Acquisition, 19(1), 37-66.

Lyster, R., \& Satio, K. (2010). Oral feedback in classroom SLA: A meta-analysis. Studies in Second Language Acquisition 32(2), 265-302.

Mackey, A., \& Philip, J. (1998). Conversational interaction and second language development: Recasts, responses, and red herrings? The Modern Language Journal, 82(3), 338-56.

Mehnert, U. (1998). The effects of different lengths of time for planning on second language performance. Studies in Second Language Acquisition, 20(1), 83108.

Nassaji, H. (2009). Effects of recasts and elicitations in dyadic interaction and the role of feedback explicitness. Language Learning 59(2): 411-452. doi:10.1111/j.1467- 9922.2009.00511.

Rassaei, E. (2013). The effects of foreign language anxiety on EFL learners' perceptions of oral corrective feedback, Innovation in Language Learning and Teaching, 1-15, DOI:10.1080/17501229.2013.837 912.

Rassaei, E. (2014). Recasts, field dependence/ independence cognitive style, and L2 development. Language Teaching Research, doi: 1362168813541713.

Saito, K., \& Lyster, R. (2012). Effects of form-focused instruction and corrective feedback on L2 pronunciation development of $/ \mathrm{x} /$ by Japanese learners of English. Language Learning, 62(2), 595633.

Sharwood Smith, M. (1993). Input enhancement in instructed SLA: Theoretical bases. Studies in Second Language Acquisition, 15(2), 156-179.

Skehan, P. (1996). A framework for the implication of task based instruction. Applied Linguistics, 17(1), 38-61.

Spada, N., E Lightbown, P. (1993). Instruction and the development of questions in L2 classrooms. Studies in Second Language Acquisition, 15(2), 205-224.

Swain, M. (1991). French immersion and its offshoots: Getting two for one. In B. Freed (Ed.), Foreign Language acquisition: Research and the classroom (pp. 91-103). Lexington, MA: Heath.

Swain, M. (1998). Focus on from through conscious reflection. In C. Doughty \& J. Williams (Eds.), Focus on from in classroom second language acquisition (pp.64-81). Cambridge: Cambridge University Press.

Trahey, M., E White, L. (1993). Positive evidence in second language classroom. Studies in Second Language Acquisition, 15(2), 181-204.

Yaghubi-Notash, M. (2007). Variability in L2: Exploring gender influence in task-prompted oral performance (Unpublished doctoral dissertation). University of Tabriz, Tabriz, Iran

Yang, Y., \& Lyster, R. (2010). Effects of form-focused practice and feedback on Chinese EFL learners' acquisition of regular and irregular past tense forms. Studies in Second Language Acquisition, 32(2), 235-263. 